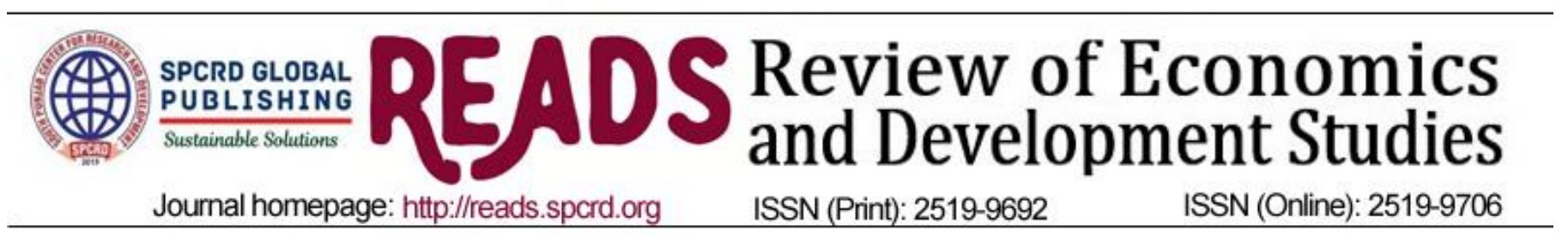

\title{
An Empirical Analysis of Organizational Performance of Construction Companies in Pakistan through Mediating Role of Conflict Management Effectiveness
}

\author{
a Haleema Tariq, ${ }^{\text {b }}$ Muqqadas Rehman \\ ${ }^{a}$ Department PhD Scholar, Superior University, Lahore, Pakistan \\ Email:haleematariq78@gmail.com \\ ${ }^{\mathrm{b}}$ Associate Professor, Hailey College of Commerce, University of the Punjab, Lahore
}

\begin{tabular}{l}
\hline ARTICLE DETAILS \\
\hline History: \\
Accepted 27 May 2020 \\
Available Online 15 June 2020 \\
\hline Keywords: \\
Conflict Management, \\
Organizational Performance, \\
Construction, Relationship \\
Conflict, Workforce Productivity
\end{tabular}

JEL Classification:

D74, D23, D29

DOI: $10.47067 /$ reads.v6i2.224

\begin{abstract}
This paper aims to examine the impact of organizational factors and verify mediating role of conflict management effectiveness on perceived performance of registered construction companies in Pakistan. The study adopts a survey research design using a well-structured questionnaire of 450 employees from construction companies located in Lahore and Karachi. The construction industry is characterized by performance setbacks for decades. Descriptive statistics and mediation analysis were employed to analyze the conceptual model. The research paper concludes that distortions in reduced workforce productivity and relationship conflicts should be overcome by capable professional \& administrative services. The analysis depicts that socio-economic and political factors play a significant role to maintain the quality in local construction industry. The findings reveal that performance of construction companies is significantly related to internal factors i.e. workforce productivity, decentralization, perceived organizational politics and relationship conflict. The study provides guidelines to organizational decision-makers and government policy-makers for public reforms in infrastructure to improve their output. The present study was undertaken to provide new horizons and advance understanding on organizational performance (OP) of construction companies in Pakistan. The most significant part of this study is the comprehensive five-factor organizational performance model designed to test mediation among variables using partial least square structural equation modelling (SEM).
\end{abstract}

(C) 2020 The authors. Published by SPCRD Global Publishing. This is an open access article under the Creative Commons Attribution-

NonCommercial 4.0

Corresponding author's email address: haleematariq78@gmail.com

\section{Introduction}

Economic globalization is embarked with an interdependent market which allows companies to transcend traditional national boundaries for conducting business overseas. The economy of developed 


\section{Review of Economics and Development Studies, Vol. 6 (2) 2020, 471-484}

and developing country consists of diverse sectors such as trade, industry, commerce and infrastructure i.e. construction. In international construction market, companies often adopt diversification as a strategy for risk management and growth. It is noted that research is scarce on the reasons of failure of performance of this sector. Although some of the projects in the construction industry are in pipeline or have failed. Even then, the construction companies are struggling to achieve desired results (Schwartz \& Deber, 2016). The volume of construction projects including roads, bridges and buildings and the complexities are expanding day by day (Yesil \& Kaya, 2013). There is a rising demand by the clients to enhance quality construction in projects. The construction companies are keen to adopt quality standards to be competitive and to minimize the relative project costs and increase overall performance (Yang, 2017).

In today's world, to address regular developmental challenges, infrastructure plays a key role as transformational path. Environmental changes, swift urbanization, social stability and natural disasters are biggest issues today (Spano, 2014). Suitable standards are yet to achieve in construction industry because countries will not be able to meet fundamental needs without an infrastructure facilitating inclusive and green expansion (Hawke, 2012). The construction sector keeps a vital position due to employment opportunities, infrastructure, shelter i.e. socio-economic objectives and its productivity. Being multifaceted in nature, the construction industry is executed by consultants, stakeholders, contractors, regulators, clients, builders and professionals (Szentes, 2018). The construction industry is among the highly unbalanced sectors due to uncertainty, project-specific demand and unpredictable demand cycles. Contractors are the significant part of project success. The construction industry is contemplated to be a supportive and significant pillar of the business environment in Pakistan.

There are deficiencies in performance mechanisms of construction firms which lead to instruction of hostile working environment and adopting sanctioning orientation which is detrimental to performance of construction sector (Das \& Kapil, 2015). Due to involvement of numerous parties in construction firms, the conflict management has been discussed a lot in recent literature (Yang, Brennan \& Wilkinson, 2014). In delivery of services by public and private administration in a country like Pakistan, conflict is a constant especially in this sector. The conflicts arise in various forms such as conflicting interests, diverse views, varying opinions (Spekle \& Verbeteen, 2014). Conflicts arise among companies' top administration, professionals, employees, labor unions and clients. The company employees have disagreements, different attitudes, opinions and views on service delivery. To be able to efficiently response to conflicts, the administration and management need to learn conflict management effectiveness. There is a misconception that conflicts are always negative but the proper handling of conflicts can give positive outcomes. So conflicts are both positive and negative (Kossova \& Sheluntcova, 2016). Hence it is pragmatic to examine the sustainability in organizational performance of construction companies due to internal organizational factors (Opute, 2014). Recent few years have witnessed a growing interest by scholars to consider workforce productivity and internal politics to manage construction sector in contrast with traditional focus on relationship conflict and conflict management.

\section{Statement of the Problem}

The study intends to examine the impact of internal organizational factors and mediating role of conflict management effectiveness on the perceived performance of construction companies in Pakistan. The growth and development of a country is led by infrastructure development of that country (Harty \& Leiringer, 2017).

\section{Purpose of Study}




\section{Review of Economics and Development Studies, Vol. 6 (2) 2020, 471-484}

The main purpose of this study is to investigate the impact of critical organizational factors on the perceived performance of construction companies in Pakistan and to determine the role of mediating variable of conflict management effectiveness.

\section{Research Objectives}

This paper is to investigate the impact of factors of organizational performance of construction companies in Pakistan by developing a conceptual model, to verify the mediating role of conflict management effectiveness and hence to establish the understanding on perceived performance of construction companies.

\section{Research Questions}

- What is the relationship of organizational factors with organizational performance?

- What is the impact of mediating variable of conflict management effectiveness in organizational performance of construction companies?

- To what extent the critical factors play successful role in performance of construction companies?

\section{Significance of the Study}

The study contributes in research and practice by identifying reasons behind underperformance of construction companies in Pakistan. This study bridges gap identified and adds knowledge in realm of conflict management by examining mediating role of conflict management effectiveness (Angogo, 2016). This research is a value-addition for practitioners, academicians, policy-makers and researchers in formulating policies for infrastructure.

\section{Limitations of the Study}

The study is limited only to selected sample due to lack of time and resources. The study might be expanded to other industries by taking macro-economic and country-specific characteristics for more meaningful implications.

\section{Literature Review}

Extensive literature review was deployed to generate critical factors believed to be influencers of organizational performance of construction companies. There is paucity of research and empirical work in construction field on the causes and effects of conflict (Haas \& Yorio, 2016).

Maiti and Choi (2018) explained 'conflict' and 'dispute' are two distinct notions. Intragroup conflicts have three distinct types: relationship, process and task conflicts. Conflict is pandemic as it exists due to incompatibility of interests. Sweet (2018) compared UK-based construction industry and chemical process industry. Construction industry can have success due to considerable impact of conflicts. Perrenoud (2018) explored the existence and management of types of intragroup conflicts in construction firms in Sri Lanka. Semi-structured interviews were conducted with three distinct participants out of each team. Results revealed that task conflicts put positive effect while both process and relationship conflicts tend to give disruptive influence on construction teams. Szentes (2018) uncovered inconsistent results for effect of perceptions of organizational politics on job performance. The theoretical model was tested with data gathered from 505 supervisors and builders. The findings demonstrated that POP had a negative effect on job performance.

Harty and Leiringer (2017) found that workforce diversification of global construction companies (GCCs) are vivid in both geographical dispersal and business sectors. Data were 


\section{Review of Economics and Development Studies, Vol. 6 (2) 2020, 471-484}

gleaned from Capital and Bloomberg. Global companies tend to diversify to geographical markets with institutional environment. Larger GCCs prefer to diversify workforce than their smaller counterparts. Companies are more prudential in venturing into new business sectors and market demands drive companies to diversify to various geographical markets. The researches provide a solid point of departure for future theoretical and empirical studies and valuable insights into diversification patterns of GCCs. Lomore and Lim, (2017) examined the elements of organizational culture of international contractors through questionnaire survey and showed that Malaysian contractors are tenderfoot in international markets. It was found that the most dominant element of organizational culture is decentralization and client orientation. This implies that there is lack of competitive advantage in international trade for international contractors. Maling (2017) found in construction industry, the term organizational performance is rapidly under debate as clients, employee and communities expect companies to demonstrate good performance financially and socially in New Zealand and Australia.

Bournakis and Tsoukis (2016) depicted that the internal organizational politics as a destructive element. During last five years, performance of construction companies as a discipline is growing in depth. Millar and Doherty (2016) investigated that in context of private construction firms, empirical researches regarding the effects of planning had covered the financial measures of performance like sales growth and profits. The other dimensions cover corporate social responsibility and employee welfare (Sole, 2009). Kossova and Sheluntcova (2016) determined that private construction companies are more finance-driven than public construction firms which are politically driven. Bobekova (2015) investigated that managers have to spend time to manage conflicts. Conflict management secures equal importance to budgeting, strategic planning and decision makings. Managers need to choose styles of conflict management (Buschor, 2013).

Das and Kapil (2015) scrutinized that often the statistics of local construction firms were unable for measuring performance regarding road and building projects. Maximum workforce productivity levels were attained by commitment and satisfaction which ultimately lead to organizational performance. Mehrad (2015) assessed that conflicts are mutual disagreements regarding task completion and relationship conflicts. The administrative strategies and decision-making bring about conflicts and power use. The organizational technology, deficient resources and heterogeneous goals provoke organizational conflicts. Villmer (2015) verified that construction firms may outperform by involvement of stakeholders, executives, contractors, builders and workforce. The internal politics act as a barrier to stop the workforce productivity and creating a gap between top administration and lower management. Evidences have proved that performance measurement models are required to estimate projects, delays, loopholes in performance, delaying tactics in public projects to gain financial benefits is common to observe.

Pang (2014) verified that project performance is directly associated to performance of construction companies. Sulle (2014) elaborated that healthy employee relationships are one of the prerequisite for success of construction firms. Construction firms are facing challenges regarding market focus, technology and size. Evidences show that the decentralized organizational cultural is significantly vital for the betterment and restructuring of construction firms within government sector, successful development comes from opting for such measures (Ogbeidi, 2012). Piening (2013) verified performance of construction industry and found that various dimensions like technical efficiency are partially financial. This research mainly focuses to identify and scrutinize the factors affecting performance of construction companies in Pakistan. 


\section{Hypotheses of the Study:}

$\mathbf{H}_{1 \mathbf{a}}$ : Workforce Productivity has significant positive relationship with perceptual conflict management effectiveness

$\mathbf{H}_{\mathbf{1}}$ : Workforce Productivity has significant positive relationship with perceived Organizational Performance

$\mathbf{H}_{\mathbf{2 a}}$ : Decentralization has significant positive relationship with perceptual conflict management effectiveness.

$\mathbf{H}_{\mathbf{2 b}}$ : Decentralization has significant positive relationship with perceived organizational performance.

$\mathbf{H}_{3 \mathbf{a}}$ : Perceived Organizational Politics has significant negative relationship with perceptual conflict management effectiveness.

$\mathbf{H}_{\mathbf{3}} \mathbf{b}$ : Perceived Organizational Politics has significant negative relationship with perceived organizational performance.

$\mathbf{H}_{\mathbf{4}} \mathbf{a}$ : Relationship conflict has significant negative relationship with perceptual conflict management effectiveness.

$\mathbf{H}_{\mathbf{4}}$ : Relationship conflict has significant negative relationship with perceived organizational performance.

$\mathbf{H}_{5}$ : Conflict Management Effectiveness has significant positive relationship with perceived organizational performance.

\section{Research Methodology}

\subsection{Research Design:}

This section draws attention on how research problem was examined based on hypotheses. This paper is quantitative in nature (Bryman, 2012). This research has been conducted from construction companies registered with Pakistan Engineering Council in Pakistan specifically located in Lahore and Karachi having majority of companies. The quantitative approach was adopted by using Survey questionnaire and primary data were gathered from professionals and employees of construction companies. Initially a pilot study was carried out using a sample of 45 respondents.

\subsection{Sample \& Data Collection Procedure:}

A structured questionnaire is pre-existing measuring tool and suitably valid for study purpose. Random sampling technique was employed for data collection. Total 465 survey questionnaires were administered in, out of which 450 were duly filled in. The items of questionnaire were adopted by the studies of (Rahim, 2002; Mehrad, 2015). The questionnaires comprises of 36 items of measures of constructs with demographic profile of respondents on 5-point Likert scale. 
Theoretical Performance Framework of the Study

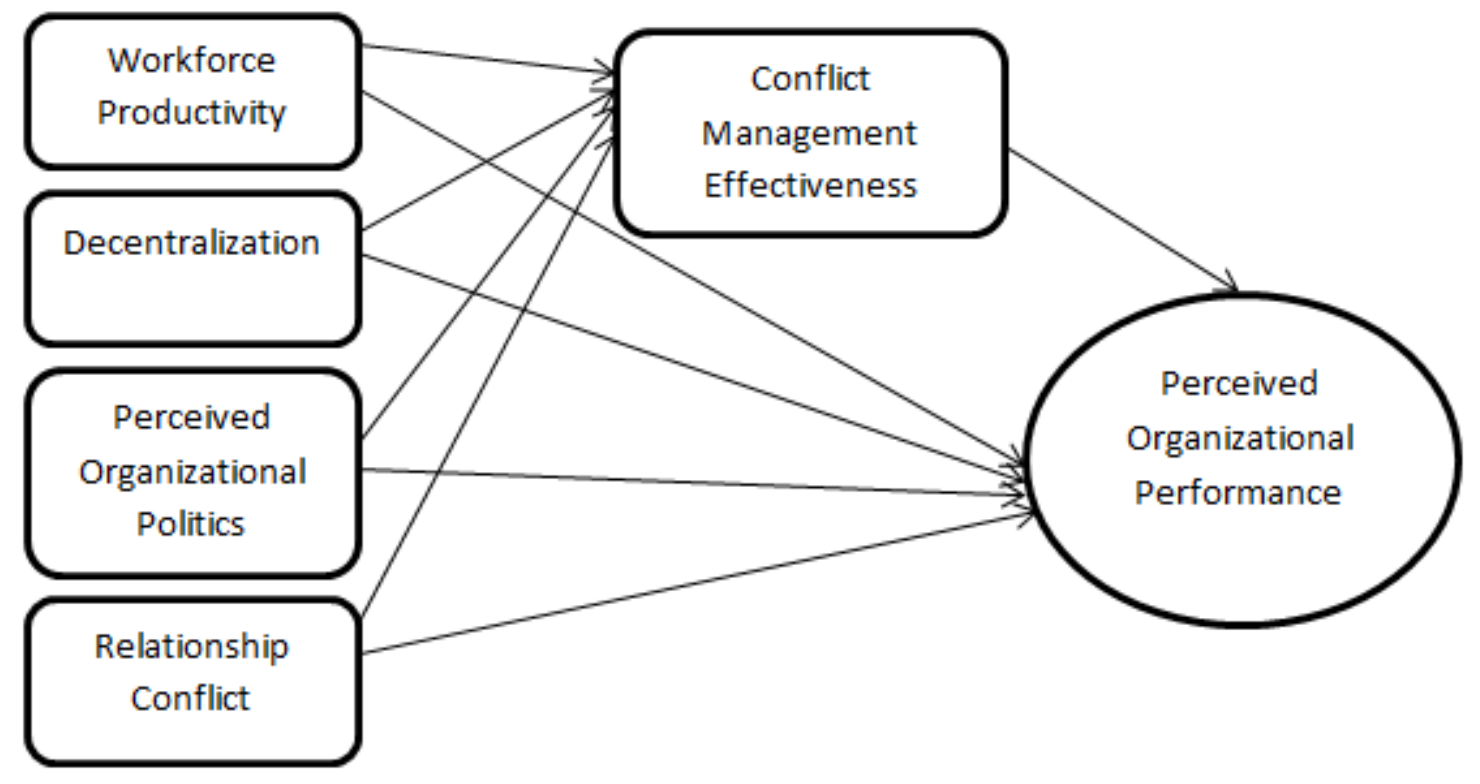

\subsection{Analyses \& Results}

\section{Table 4.1 : Reliability Analysis}

\begin{tabular}{|l|l|l|}
\hline Variables & Cronbach's Alpha & No. of Items \\
\hline Workforce Productivity & 0.895 & 3 \\
\hline Decentralization & 0.880 & 3 \\
\hline Perceived Organizational Politics & 0.919 & 6 \\
\hline Relationship Conflict & 0.906 & 4 \\
\hline Conflict Management Effectiveness & 0.861 & 15 \\
\hline Perceived Organizational Performance & 0.920 & 5 \\
\hline
\end{tabular}

The cronbach alpha values of constructs are higher for the current sample showing the measures are internally consistent and reliable.

Table 4.2: Descriptive Statistics for the Variables

\begin{tabular}{|l|l|l|l|l|l|}
\hline Variables & $\mathbf{N}$ & Minimum & Maximum & Mean & Std. Dev \\
\hline $\begin{array}{l}\text { Workforce } \\
\text { Productivity }\end{array}$ & 450 & 1.00 & 5.00 & 3.2141 & 1.3843 \\
\hline Decentralization & 450 & 1.00 & 5.00 & 3.4141 & 1.3505 \\
\hline $\begin{array}{l}\text { Perceived } \\
\text { Organizational } \\
\text { Politics }\end{array}$ & 450 & 1.00 & 5.00 & 3.2152 & 1.2804 \\
\hline $\begin{array}{l}\text { Relationship } \\
\text { Conflict }\end{array}$ & 450 & 1.00 & 5.00 & 3.0689 & 1.3579 \\
\hline $\begin{array}{l}\text { Conflict } \\
\text { Management } \\
\text { Effectiveness }\end{array}$ & 450 & 1.00 & 5.00 & 3.2596 & 1.3789 \\
\hline Organizational & 450 & 1.00 & 5.00 & 3.4462 & 1.2784 \\
\hline
\end{tabular}


Review of Economics and Development Studies, Vol. 6 (2) 2020, 471-484

The descriptive statistics of mean values are overall average responses of majority of respondents. Standard deviation values indicate dispersal of values from their respective average central point. Data depicts lesser dispersions from their central point.

Table 4.3: Confirmatory Factor Analysis (CFA)

\begin{tabular}{|l|l|l|}
\hline Variables & KMO \& Bartlett's Test & Sig. \\
\hline Workforce Productivity & 0.750 & .000 \\
\hline Decentralization & 0.745 & .000 \\
\hline Perceived Organizational Politics & 0.910 & .000 \\
\hline Relationship Conflict & 0.847 & .000 \\
\hline Conflict Management Effectiveness & 0.827 & .000 \\
\hline Organizational Performance & 0.894 & .000 \\
\hline
\end{tabular}

The factor analysis show KMO values are good being greater than o.6. Bartlett's test has a null hypothesis of no correlation. Above table proves the p-values are less than the 0.001 confirm the significant relationships among variables.

Table 4.4: Correlation Matrix

\begin{tabular}{|c|c|c|c|c|c|c|}
\hline & WP & DCT & RC & POP & CME & OP \\
\hline \multirow[t]{2}{*}{ Workforce Productivity } & 1 & & & & & \\
\hline & - & & & & & \\
\hline \multirow[t]{2}{*}{ Decentralization } & $0.317^{* *}$ & 1 & & & & \\
\hline & .000 & - & & & & \\
\hline \multirow[t]{2}{*}{ Relationship Conflict } & $0.224^{* *}$ & $0.265^{* *}$ & 1 & & & \\
\hline & .000 & .000 & - & & & \\
\hline \multirow[t]{2}{*}{$\begin{array}{l}\text { Perceived Organizational } \\
\text { Politics }\end{array}$} & $0.143^{* *}$ & $0.348 * *$ & $0.357^{* *}$ & 1 & & \\
\hline & .002 & .000 & .000 & - & & \\
\hline \multirow[t]{2}{*}{$\begin{array}{ll}\text { Conflict } & \text { Management } \\
\text { Effectiveness } & \\
\end{array}$} & $0.336^{* *}$ & $0.435^{* *}$ & $0.393^{* *}$ & $0.431^{* *}$ & 1 & \\
\hline & .000 & .000 & .000 & .000 & - & \\
\hline \multirow[t]{2}{*}{$\begin{array}{l}\text { Organizational } \\
\text { Performance }\end{array}$} & $0.402 * *$ & $0.366 * *$ & $0.147^{* *}$ & $0.302^{* *}$ & $0.495^{* *}$ & 1 \\
\hline & .000 & .000 & .002 & .000 & .000 & - \\
\hline
\end{tabular}

${ }^{* *}$ Correlation is significant at the 0.01 level (2-tailed)

This matrix addresses research questions and depicts that all variables have highly significant and positive relationships with each other. 


\subsection{Graphical Output of Conceptual Model of Study}

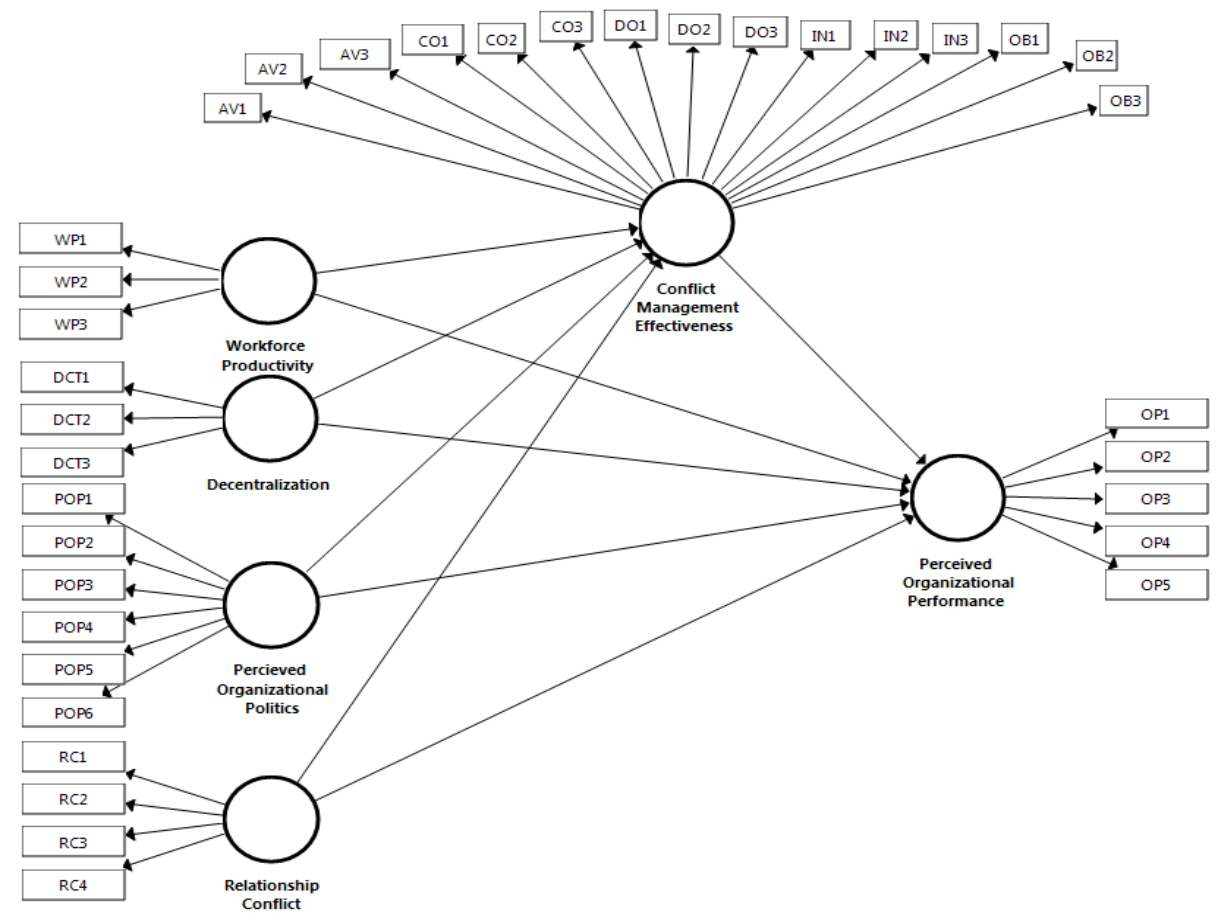

\subsection{Structural Assessment Model Assessment}

For theory building, this multivariate data analysis method is an optimal statistical tool which does not assume normality of data. On the basis of principal component, PLS-SEM is suitable statistical method (Hair, Hult, Ringle, \& Sarstedt, 2017). The path coefficients and significance of estimated values is tested through this method (Henseler, Ringle, \& Sarstedt, 2012).

\section{Table 4.5: Construct Reliabilty and Convergent Validity}

\begin{tabular}{|l|l|l|}
\hline Constructs & $\begin{array}{l}\text { Composite Reliability } \\
\text { (CR) }\end{array}$ & $\begin{array}{l}\text { Average Variance Explained } \\
\text { (AVE) }\end{array}$ \\
\hline CME & 0.885 & 0.543 \\
\hline DCT & 0.926 & 0.806 \\
\hline OP & 0.940 & 0.758 \\
\hline POP & 0937 & 0.714 \\
\hline RC & 0.934 & 0.781 \\
\hline WP & 0.935 & 0.827 \\
\hline
\end{tabular}

The constructs supposed to be related, are actually related shown by values good enough for the data set. 
Review of Economics and Development Studies, Vol. 6 (2) 2020, 471-484

Table 4.6: Collinearity Statisitcs (VIF) Inner VIF values

\begin{tabular}{|l|l|l|}
\hline Constructs & $\begin{array}{l}\text { Conflict Management } \\
\text { Effectiveness }\end{array}$ & $\begin{array}{l}\text { Perceived Organizational } \\
\text { Performance }\end{array}$ \\
\hline $\begin{array}{l}\text { Conflict Management } \\
\text { Effectiveness }\end{array}$ & - & 1.549 \\
\hline Decentralization & 1.257 & 1.359 \\
\hline Perceived Organizational Politics & 1.245 & 1.338 \\
\hline Relationship Conflict & 1.203 & 1.252 \\
\hline Workforce Productivity & 1.137 & 1.195 \\
\hline
\end{tabular}

VIF values are below than cut off value 5 indicating a good sign of data free from multicollinearity issue.

Table 4.7 : Discriminant Validity Heterotrait-Monotrait Ratio (HTMT)

\begin{tabular}{|l|l|l|l|l|l|l|}
\hline Latent Variables & CME & DCT & OP & POP & RC & WP \\
\hline $\begin{array}{l}\text { Conflict Management } \\
\text { Effectiveness }\end{array}$ & 0.586 & & & & & \\
\hline Decentralization & 0.450 & 0.898 & & & & \\
\hline $\begin{array}{l}\text { Perceived Organizational } \\
\text { Performance }\end{array}$ & 0.506 & 0.365 & 0.871 & & & \\
\hline $\begin{array}{l}\text { Perceived Organizational } \\
\text { Politics }\end{array}$ & 0.426 & 0.348 & 0.302 & 0.845 & & \\
\hline Relationship Conflict & 0.377 & 0.266 & 0.147 & 0.358 & 0.883 & \\
\hline Workforce Productivity & 0.349 & 0.316 & 0.404 & 0.143 & 0.222 & 0.909 \\
\hline
\end{tabular}

The discriminant validity values are satisfactory. The table shows that the constructs which should haven't relationship with each other, have no relationship. The values of discriminant validity also support reliability and internal consistency of measurement model.

Table 4.8: Model Fit Summary

\begin{tabular}{|l|l|l|}
\hline Fit Summary & Saturated Model & Estimated/Default Model \\
\hline SRMR & 0.048 & 0.048 \\
\hline NFI & 0.701 & 0.701 \\
\hline
\end{tabular}

The values of both default model and saturated model are equal. Standardized Root Mean Square Residual (SRMR) is an absolute measure of fit $=0.048$. For a good fit model, it is suggested that SRMR value of residual and error should be less than cut off value 0.05. For Normed Fit Index (NFI), NFI value should be equal to or greater than 0.90 i.e. between o-1. The value of Normed Fit index in default model $=0.701$ is a good fit.

\subsection{Assessment of Structural Model/Inner Model}

In PLS-SEM, assessment of structural model includes path coefficients to verify the significance and relevance of relationships of structural model (Hair, Hult, Ringle, \& Sarstedt, 2017). 


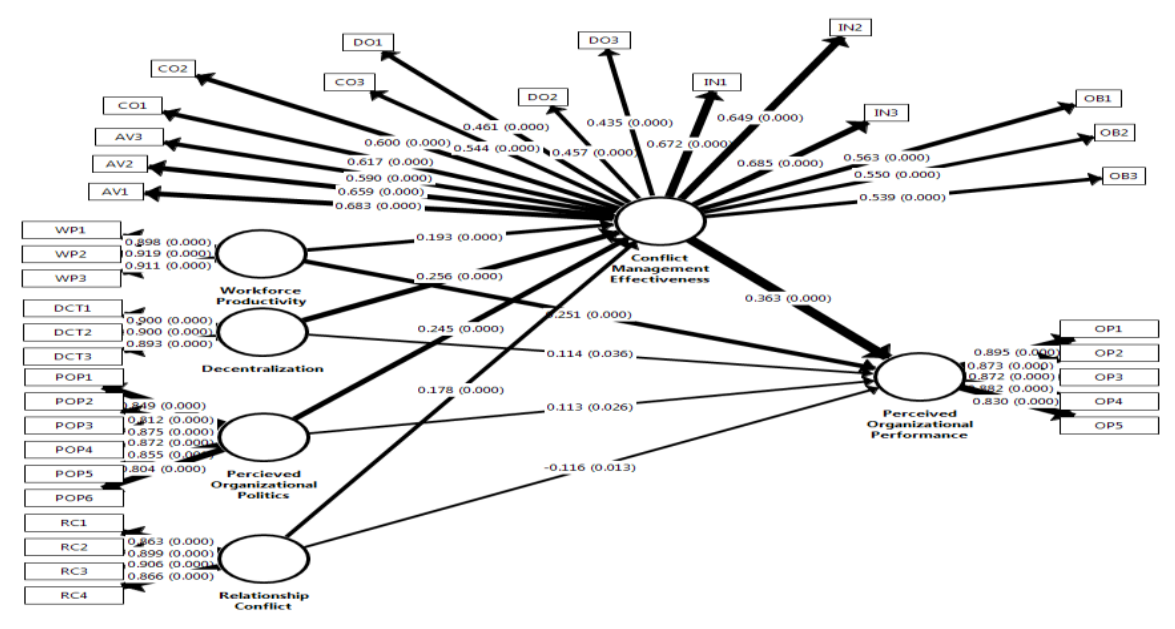

Table 4.9: Path Coefficients for Direct Effects of Variables

\begin{tabular}{|l|l|l|l|l|}
\hline $\begin{array}{l}\text { Relationships between } \\
\text { Constructs }\end{array}$ & $\begin{array}{l}\text { Estimate or } \\
\text { Original Sample } \\
\text { Mean (O) }\end{array}$ & Std. Dev & T-Stat & P Values \\
\hline CME -> Perceived OP & 0.363 & 0.052 & 6.949 & 0.000 \\
\hline WP-> CME & 0.193 & 0.043 & 4.452 & 0.000 \\
\hline WP -> Perceived OP & 0.251 & 0.045 & 5.626 & 0.000 \\
\hline DCT -> CME & 0.256 & 0.044 & 5.859 & 0.000 \\
\hline DCT -> Perceived OP & 0.114 & 0.054 & 2.103 & 0.036 \\
\hline POP-> CME & 0.245 & 0.042 & 5.906 & 0.000 \\
\hline POP -> Perceived OP & -0.113 & 0.051 & 2.231 & 0.026 \\
\hline RC -> CME & 0.178 & 0.047 & 3.818 & 0.000 \\
\hline RC -> Perceived OP & -0.116 & 0.046 & 2.493 & 0.013 \\
\hline
\end{tabular}

Bootstrapping is a non-parametric approach used to assess path coefficients and their direct effects. The workforce productivity and decentralization are significantly related to conflict management effectiveness and organizational performance whereas the remaining two variables of perceived organizational politics and relationship conflicts were negatively associated with organizational performance but due to the mediating variable, these two variables become positively and significantly related to perceived organizational performance.

Table 4.10: Indirect Effects of Variables

\begin{tabular}{|l|l|l|l|l|}
\hline $\begin{array}{l}\text { Relationships between } \\
\text { Constructs }\end{array}$ & $\begin{array}{l}\text { Estimate/Original } \\
\text { Sample Mean (O) }\end{array}$ & Std. Dev & T-Stat & $\begin{array}{l}\mathbf{P} \\
\text { Values }\end{array}$ \\
\hline WP -> Perceived OP & 0.070 & 0.018 & 3.812 & 0.000 \\
\hline DCT -> Perceived OP & 0.093 & 0.022 & 4.249 & 0.000 \\
\hline POP -> Perceived OP & 0.089 & 0.022 & 4.061 & 0.000 \\
\hline RC -> Perceived OP & 0.065 & 0.019 & 3.425 & 0.001 \\
\hline
\end{tabular}

Here all the estimate values are statistically significant indicated by p-values. The standard deviation values show the measures used to quantify the amount of dispersion of data set values. The $\mathrm{T}$ 
values are also good for the model.

Table 4.11: Mediation Analyses \& Hypotheses Testing

\begin{tabular}{|l|l|l|l|l|l|}
\hline & $\begin{array}{l}\text { Direct } \\
\text { Effect }\end{array}$ & $\begin{array}{l}\text { P } \\
\text { Value }\end{array}$ & $\begin{array}{l}\text { Indirect } \\
\text { Effect }\end{array}$ & $\begin{array}{l}\text { P } \\
\text { Value }\end{array}$ & $\begin{array}{l}\text { Mediation } \\
\text { Type }\end{array}$ \\
\hline $\begin{array}{l}\text { Workforce Productivity -> } \\
\text { Organizational Performance }\end{array}$ & 0.251 & 0.000 & 0.070 & 0.000 & $\begin{array}{l}\text { Partial } \\
\text { Mediation }\end{array}$ \\
\hline $\begin{array}{l}\text { Decentralization -> } \\
\text { Organizational Performance }\end{array}$ & 0.114 & 0.036 & 0.093 & 0.000 & $\begin{array}{l}\text { Partial } \\
\text { Mediation }\end{array}$ \\
\hline $\begin{array}{l}\text { Perceived Organizational } \\
\text { Politics -> Organizational } \\
\text { Performance }\end{array}$ & -0.113 & 0.026 & 0.089 & 0.000 & $\begin{array}{l}\text { Full } \\
\text { Mediation }\end{array}$ \\
\hline $\begin{array}{l}\text { Relationship Conflict -> } \\
\text { Organizational Performance }\end{array}$ & -0.116 & 0.013 & 0.065 & 0.001 & $\begin{array}{l}\text { Full } \\
\text { Mediation }\end{array}$ \\
\hline
\end{tabular}

The WP has directly positive and significant impact on OP while this impact decreases due to mediator CME. Thus, CME partially mediates between the relationship of WP and OP as direct effect is greater than the indirect effect. The DCT has directly positive and significant impact on OP while this impact decreases due to CME. Thus CME partially mediates between DCT and OP. The POP has negatively significant impact on OP but due to mediator CME, POP puts a positively significant influence on OP. Thus CME fully mediates between POP and OP. Likewise, CME fully mediates between RC and OP. There is a partial mediation in case of workforce productivity and decentralization whereas full mediation exists in case of perceived organizational politics and relationship conflicts.

Table 4.12: Results Summary

\begin{tabular}{|l|l|l|}
\hline & Hypotheses of the Study & $\begin{array}{l}\text { Result-based } \\
\text { Decision }\end{array}$ \\
\hline $\mathrm{H}_{1 \mathrm{a}}$ & WP has significant positive relationship with perceptual CME. & Supported \\
\hline $\mathrm{H}_{1 \mathrm{~b}}$ & WP has significant positive relationship with perceived OP. & Supported \\
\hline $\mathrm{H}_{2 \mathrm{a}}$ & $\begin{array}{l}\text { DCT has significant positive relationship with perceptual } \\
\text { CME. }\end{array}$ & Supported \\
\hline $\mathrm{H}_{2 \mathrm{~b}}$ & DCT has significant positive relationship with OP. & Supported \\
\hline $\mathrm{H}_{3 \mathrm{a}}$ & $\begin{array}{l}\text { POP has significant negative relationship with perceptual } \\
\text { CME. }\end{array}$ & Not Supported \\
\hline $\mathrm{H}_{3 \mathrm{~b}}$ & POP has significant negative relationship with OP. & Supported \\
\hline $\mathrm{H}_{4 \mathrm{a}}$ & RC has significant negative relationship with perceptual CME. & Not Supported \\
\hline $\mathrm{H}_{4 \mathrm{~b}}$ & RC has significant negative relationship with OP. & Supported \\
\hline $\mathrm{H}_{5}$ & CME has significant positive relationship with perceived OP. & Supported \\
\hline
\end{tabular}

\section{Discussion}

The ultimate goal of this research is to derive some useful implications to help executives of construction companies (Jung \& Kim, 2014). The empirical analysis of organizational performance in construction is undertaken through an integrative conceptual framework. The findings demonstrate potential value of all theoretical concepts in moving this phenomenon forward. The results enlighten the potential impact of organizational theory on demographic and organizational variables (Mensah, 2013). The objectives of this study are now well-answered through these analyses of data sample. The 


\section{Review of Economics and Development Studies, Vol. 6 (2) 2020, 471-484}

impact of five core factors has been assessed through mediation to verify impact of factors of organizational performance of construction companies in Pakistan. The paradoxical tension of relationship conflict and internal politics with perceived performance is recognized which becomes a blessing in disguise when mediator mediates in between them (Yang, 2017). The decentralization is another momentous measure in analyzing organizational performance. The relationship conflict is revealed as major type of conflict. The mediating role of conflict management effectiveness has been examined that in case of workforce productivity and decentralization, conflict management effectiveness partially mediates the mutual relationships whereas conflict management effectiveness fully meditates in case of remaining two variables i.e. perceived organizational politics and relationship conflicts in determining the organizational performance of construction companies. A conceptual model was also developed for set of critical factors of organizational performance and the understanding on overall quality performance of construction companies were established (Sweet, 2018). It is pertinent that value-addition point is about mediating role of conflict management effectiveness. Because before mediation, the perceived organizational politics and relationship conflicts were negatively affecting the performance of construction companies but after the mediation of conflict management effectiveness, both the variables put a positively significant impact on the organizational performance (Harty \& Leiringer 2017; Schwartz \& Deber, 2016).

\section{Conclusion}

Conflicts prove to be an unavoidable part of organization. This study focuses to verify effectiveness of conflict management in the construction industry. Although professional quality management in construction projects is being practiced however due negligence and unavoidable flaws are still existent in local practices on the basis of mutual relationships among the stakeholders (Villmer, 2015). All identified factors have high significance in conceptual model. The study provides insights on comprehending the critical challenges being faced by construction companies which inhibit the organizational performance in a developing country like Pakistan. Conflict is intrinsic to organizations, teams and individuals. Conflicts are inevitable in construction companies as they have complex and unique nature with various parties (Szentes, 2018). The construction business environment has become more intense and competitive. The competitive advantage in construction field is created by higher workforce productivity, more decentralized organizational environment, lesser perceived organizational politics, less relationship conflicts and more conflict management effectiveness. It is worthy to mention here that perceived organizational politics and relationship conflicts turn their negative impact on organizational performance into positive effect in presence of mediator conflict management effectiveness (Chen, 2015). The construction companies cannot overlook workforce productivity, decentralized working environment, conflicts and internal politics. The findings revealed that the performance of construction companies is influenced by critical factors. The conclusion is to systematically reintegrate tackle the conflicts by introducing the mediation as flexible and informal method to reach a settlement which is mutually acceptable (Harty \& Leiringer, 2017). In today's global construction market, sustainable business models can improve performance in terms of market competitiveness, growth and profitability. Consequently, the study provides helpful guidelines to assist decision-making of executives to design a business model enabling construction firms to thrive in global marketplace (Manning, 2017; Arogundade, 2016). The study makes useful contributions in research and practice. The body of knowledge is extended by conceptual model which offers potential sources to achieve competitive advantage in construction sector. This study contributes to literature of conflict and construction management. The taxonomy for upcoming researches may be advanced to investigate quality management systems for ensuring safety and security in construction projects. A comparison might be made with other growing sectors of an economy to view broader picture of the phenomenon. 


\section{Review of Economics and Development Studies, Vol. 6 (2) 2020, 471-484}

\section{References}

Amayah, A. T. (2013). Determinants of knowledge sharing in a public sector organization. Journal of Knowledge Management, 17(3), $454-471$.

Angogo, F. A. (2016). The Influence of Organizational Politics on Career Development Among Administrative Staff in Public Universities: A Case of the University of Eldoret, Kenya (Doctoral dissertation, COHRED, JKUAT).

Arogundade, O. T. (2016). A Psychological Appraisal of Perceived Organizational Politics in Selected Profit and Non-Profit Organizations in Lagos Metropolis, Nigeria. Ife PsychologIA, 24(1).

Bobekova, E. (2015). Third party conflict management of trans boundary river disputes", International Journal of Conflict Management, 26 (4), $402-426$.

Bournakis, I., \& Tsoukis, C. (2016). Government size, institutions, and export performance among OECD economies. Economic Modelling, 53, 37-47.

Bryman, A. (2012). 'Social Research Methods' (4th Ed.). Oxford University Press.

Buschor, E. (2013). Performance Management in the public sector: Past, current and future trends. Review of Applied Management Studies, 11, 4-9.

Chen, T. (2015). Institutions, board structure, and corporate performance: Evidence from Chinese firms. Journal of Corporate Finance, 32, 217-237. Doi: 10.1016/j.jcorpfin.2014.10.009.

Das , A., \& Kapil , S. (2015). Inorganic growth of technology sector firms in emerging markets: Influence of firm-specific factors in Indian firms' M\&A activities. International Journal of Emerging Markets, 10 (1), $52-72$.

Haas, E. J., \& Yorio, P. (2016). Exploring the state of health and safety management system performance measurement in mining organizations. Safety Science, 83, 48-58. Doi: 10.1016/j.ssci.2015.11.009.

Hair, J. F., Hult, G. T. M., Ringle, C. M., and Sarstedt, M. (2017). A Primer on Partial Least Squares Structural Equation Modeling (PLS-SEM), 2nd Ed., Thousand Oaks, CA: Sage.

Harty, C. \& Leiringer, R. (2017). The futures of construction management research, Construction Management and Economics, 35(7), 392 403, DOI: 10.1080/01446193.2017.1306089.

Hawke, L. (2012). Australian public sector performance management: success or stagnation? International Journal of Productivity and Performance Management, 61(3), $310-328$.

Henseler, J., Ringle, C. M., and Sarstedt, M. (2012). Using Partial Least Squares Path Modeling in International Advertising Research: Basic Concepts and Recent Issues, in Handbook of Research in International Advertising.

Jung, C. S., \& Kim, S. E. (2014). Structure and Perceived Performance in Public Organizations. Public Management Review, 16 (5), 620-642.

Kossova, T., \& Sheluntcova, M. (2016). Evaluating performance of public sector projects in Russia: The choice of a social discount rate. International Journal of Project Management, 34, 403-411.

Lomore, M. \& Lim, B. T. (2017). Linking corporate social responsibility and organizational performance in the construction industry, Construction Management and Economics, 35(3), 90105, DOI: 10.1080/01446193.2016.1242762.

Maiti, S. \& Choi, J. (2018) Investigation and implementation of conflict management strategies to minimize conflicts in the construction industry, International Journal of Construction Management, DOI: 10.1080/15623599.2018.1536964.

Maling, M. A. (2017). The Study of High-Cost Oncology Patients to Improve Care \& Curb Costs, Oncology Issues, 32:3, 46-53, DOI: 10.1080/10463356.2017.11884180

Martocchio, J. J. (2006). Strategic Compensation - A Human Resource Management Approach. New Jersey: Pearson Education, Inc.

Mehrad, A. (2015). Conflict Management Styles and Staff Job Satisfaction at Organization. Journal of Educational, Health and Community Psychology, 4(2), 98-104.

Mensah, G. T. (2013). Relationship Between Perceived Organizational Politics, Organizational 


\section{Review of Economics and Development Studies, Vol. 6 (2) 2020, 471-484}

Commitment and Organizational Citizenship Behavior Among Some Selected Public Sector Organizations in Accra (Doctoral dissertation, University of Ghana).

Millar, P., \& Doherty, A. (2016). Capacity building in nonprofit sport organizations: Development of a process model. Sport Management Review, xxx, xxx-xxx. Doi: 10.1016/j.smr.2016.01.002.

Ofori, E. (2014). The Relationships between Perceived Organisational Politics, Employee Political Skill and Job Stress among Employees in the Ghanaian Private Sector (Doctoral dissertation, University of Ghana).

Ogbeidi, M.M. (2012). Political Leadership and Corruption in Nigeria Since 1960: A Socio-economic Analysis. Journal of Nigeria Studies,1(2), 1-25.

Opute, A. P. (2014). Cross-functional bridge in dyadic relationship: Conflict management and performance implications, Team Performance Management, 20(3/4), 121 - 147.

Otmazgin, N. K. (2013). Regionalizing Culture. University of Hawai'i Press.

Pang, M. (2014). IT governance and business value in the public sector organizations _ The role of elected representatives in IT governance and its impact on IT value in U.S. state governments. Decision Support Systems, 59, 274-285.

Perrenoud, A. J. (2018). Delphi Approach to Identifying Best Practices for Succession Planning within Construction Firms, International Journal of Construction and Research, DOI: 10.1080/15578771.2018.1544950

Piening, E. P. (2013). Dynamic Capabilities in Public Organizations, Public Management Review, 15(2), 209-245.

Rahim, M. A. (2002). Toward a Theory of Managing Organizational conflicts. The International Journal of Conflict Management,13(3), 206-235.

Sardana G. D. (2008). Measuring business performance: a conceptual framework with focus on improvement. Performance Improvement, 47(7). DOI: 10.1002/pfi.20014.

Schwartz, R., \& Deber, R. (2016). The performance measurement-management divides in public health. Health Policy. Doi: 10.1016/j.healthpol.2016.02.003.

Sole, F. (2009). A management model and factors driving performance in public organizations. Measuring Business Excellence, 13(4), 3 - 11.

Spano, A. (2014). How do we measure public value? From Theory to Practice. Public Value Management, Measurement and Reporting, 3, 353-373.

Spekle, R. F., \& Verbeteen, F. H.M. (2014). The use of performance measurement systems in the public sector: Effects on performance. Management Accounting Research, 25, 131-146. Doi: 10.1016/j.mar.2013.07.004.

Sulle, A. (2014). The Use of Performance Measurement Information in the Tanzanian Public sector: The case of National Housing Corporation. International Journal of Management Sciences and Business Research, 3(7), 1-10.

Sweet, R. (2018). Canary in the coal mine: What Carillion's collapse reveals about construction's productivity conundrum, Construction Research and Innovation, 9:1, 3-8, DOI: 10.1080/20450249.2018.1447062.

Szentes, H (2018). Reinforcing cycles involving inter- and intraorganizational paradoxical tensions when managing large construction projects, Construction Management and Economics, 36(3), 125140, DOI: 10.1080/01446193.2017.1315826.

Villmer, A. (2015). Conflicts in innovation and how to approach the "last mile" of conflict management research - A literature review, International Journal of Conflict Management, 26(2), 192 - 213.

Yang, F. (2017). Better understanding the perceptions of organizational politics: its impact under different types of work unit structure, European Journal of Work and Organizational Psychology, 26(2), 250262, DOI: $10.1080 / 1359432 X .2016 .1251417$

Yesil, S., \& Kaya, A. (2013). The effect of organizational culture on firm financial performance: Evidence from a developing country. Procedia-Social and Behavioral Sciences, 81, 428-437. 